\title{
DEATH ROW INMATES OR ORGAN DONORS: CHINA'S SOURCE OF BODY ORGANS FOR MEDICAL TRANSPLANTATION
}

\section{INTRODUCTION}

China is using condemned prisoners as the principal source of body organs for medical transplantation purposes. ${ }^{1}$ The body parts of executed prisoners are removed immediately after execution by a waiting medical staff without the prisoner's consent. In some cases, executions are deliberately mishandled to ensure that the prisoners are not yet dead when their organs are removed. ${ }^{2}$ Executions appear to be scheduled according to transplant needs. ${ }^{3}$ "The procedure is coordinated by the relevant health officials 'in accordance with the degree and urgency of need'."4 Organs are given to government authorities or sold to patients awaiting transplant surgery from other countries, particularly Hong Kong. It is believed that as many as twelve hospitals in Guangdong alone provide organs to meet emergent transplant requirements in Hong Kong. ${ }^{s}$ Most of these organs sent to Hong Kong are removed from executed prisoners. One of Hong Kong's top renal specialists, Dr. George Chan Man-Kam, refers patients to China to receive the kidneys of executed prisoners. ${ }^{6}$ Dr. Chan declined to reveal the number of kidney patients he sends to China for transplants, but said it was more than the fifty-three who underwent transplant operations in Hong Kong last year. ${ }^{7}$

1. China: Organ Procurement and Judical Execution in China, HUMAN RIGHTS WATCh/AsIA (Human Rights Watch/Asia, New York, N.Y.), Vol. 6, No. 9, Aug. 1994, at 2 [hereinafter HUMAN RIGHTS WATCH/ASIA]. Human Rights Watch/Asia is a non-governmental organization established in 1978 to monitor and promote the observance of internationally recognized human rights.

2. Id. at 3. According to HUMAN RIGHTS WATCH/ASIA, id, sometimes executions are intentionally botched so that a victim can be kept alive longer, thereby increasing the viability of organ transplantation. Plus, vivisection (experimentation) may occur. Id. at 28. See also Allegations of Organs Trade in China Spark off Furore, The STRATTS TIMES (SINGAPORE), Nov. 18, 1994, at 20 (A Chinese doctor now living in the West related his experience with a transplant operation in which he was given the task of removing both kidneys from a prisoner who was still alive.).

3. Id. at 28 .

4. Lena H. Sun, China's Executed Convicts Donate Organs Unwittingly, WASH. POST, March 27, 1994, at A22.

5. Mariana Wan, Transplant Patients in AIDS Peril, South ChINA MORNING Post, July 18, 1993, at 14 .

6. Queenie Wang, Medic Linked to Prison Kidney Transplants; Hong Kong Medic in Mainland Referrals; "Anyway their organs will be thrown away after they die. ", SOUTH CHINA MORNING POST, Oct. 30, 1994, at 1. See also Allegations of Organs Trade in China Spark Off Furore, THE STRAITS TIMES (SINGAPORE), Nov. 18, 1994. Dr. Chan is informed of execution dates by a network of his former students who now work on the mainland. "They find out from the notices posted by the courts, and they call me." Id.

7. Id. 
Despite campaigns to increase organ donations, donors are still in short supply in Hong Kong. ${ }^{8}$ This shortage forces patients to visit the mainland for transplants, although many Hong Kong residents who have undergone kidney transplants in China are known to have experienced serious medical problems after their operations. ${ }^{9}$ Desperate patients will not stop going to China to buy organs of executed prisoners until there are enough organs donations in Hong Kong to meet the demand. ${ }^{10}$ While visiting Guangdong, Professor Arthur Li, dean of the medical facility at the Chinese University of Hong Kong, was offered kidneys by the Chinese hospital staff. ${ }^{11}$ Professor Li was willing to take the organs back to Hong Kong for transplant purposes provided they were free and he received proof of consent from the prisoners. After stating these conditions, he heard nothing further about the offer.

Reports of organ harvesting of condemned prisoners have been confirmed by doctors and judges who were present at the executions, and most compelling, by members of the Communist Party in China. ${ }^{12}$ Restricted circulation documents acknowledge that these practices occur, even to the point of conceding that in some cases, organs were removed from living prisoners. ${ }^{13}$ The United Nations Committee Against Torture summarized official comments made in April 1993 by China's delegation to the United Nations, led by Ambassador Jin Yongiian as follows: "Removal of organs without the permission of either the person or his family was not standard practice. There were, however, cases in which permission had been given to remove organs from the bodies of the persons executed."14

It is estimated that 2,000 to 3,000 organs (mostly kidneys and corneas) are removed from prisoners each year and used in transplant procedures. ${ }^{15}$ One Chinese government document describes chilling details of how the harvesting of the organs should be carried out.

The use of the corpses or organs of executed criminals must be kept strictly secret, and attention must be paid to avoiding negative repercussions. [The removal of organs] should normally

8. Alison Wiseman, Prisoners' Organ Trade 'Will Go On, ' SOUTH CHNA MORNING Post, Aug. 30, 1994, at 6.

9. Id.

10. Id.

11. Mariana Wan \& Simon Beck, Organs of Prisoners Used in Operations, SOUTH CHINA MORNING POST, July 25, 1993, at 1.

12. See HUMAN RIGITS WATCH/ASIA, supra note 1 , at 7-8.

13. ALL THINGS CONSIDERED, (National Public Radio, Aug. 29, 1994), available in LEXIS, NEXIS Library, Scripts File).

14. U.N. GAOR Comm. Against Torture, 48th Sess., Supp. No. 44A, U.N. Doc. A/48/44/Add. 1 (1993).

15. HUMAN RIGHTS WATCH/ASIA, supra note 1 , at 2. 
be carried out within the utilizing unit. Where it is genuinely necessary, then with the permission of the people's court that is carrying out the death sentence, a surgical vehicle from the health department may be permitted to drive onto the execution grounds to remove the organs, but it is not permitted to use a vehicle bearing health department insignia or to wear white clothing. Guards must remain posted around the execution grounds while the operation for organ removal is going on. ${ }^{16}$

This Comment primarily focuses on the violations of Chinese and international law committed by the government of the People's Republic of China in the sanctioning of organ removal from executed prisoners without their consent. In addition, this Comment focuses on possible ways in which the government of the People's Republic of China can increase voluntary participation by its citizens in an organ donor program, and ways in which other countries, international companies, and the medical society can apply pressure on the Chinese government to stop the human rights violations occurring in China's prisons with regard to the procurement of organs.

\section{FACTORS CONTRIBUTING TO THE EXPANSION AND SUCCESS of ORgan TRANSPLANTATION IN CHINA}

China's organ transplantation program began during the 1960's, when a number of kidney transplant operations were conducted with the help of foreign medical advisors. ${ }^{17}$ Although there were a number of kidney, liver, heart, and lung transplants across the country in the late 1970's, the success rate remained low and by the early 1980's, the country's organ program appeared to be faltering. ${ }^{18}$ In 1983 , two unrelated factors combined to give the program a major boost, and provide a foundation for the new expansion and success of organ transplantation in China. One was the introduction of Cyclosporine A (CsA), a drug which inhibits the body's natural tendency to reject foreign body tissue. The other was the commencement of a series of "crackdown on crime" campaigns which greatly increased the number of criminals sentenced to death. ${ }^{19}$

16. Temporary Rules Concerning the Utilization of Corpses or Organs from the Corpses of Executed Criminals, Oct. 9, 1984, reprinted in HUMAN RIGHTS WATCH/ASIA, supra note 1, app. at 36.

17. HUMAN RIGHTS WATCH/ASIA, supra note 1 , at 4. The organ transplantation program was not publicly announced until 1974. Id.

18. Id.

19. Id. at 4. 


\section{A. Cyclosporine A "The Wonder Drug"}

Cyclosporine A, an immunosuppresive agent which inhibits the body's natural tendency to reject foreign body tissue, was introduced into China in the mid-1980's by the Swiss company Sandoz. ${ }^{20}$ The drug raised the first year survival rate for recipients of kidney transplants from fifty to eighty percent. By 1991, the survival rate rose to more than ninety percent. ${ }^{21}$ In addition to raising the transplantation program's success rate, Cyclosporine A also introduced a major financial element into the organ transplantation process. The drug's high price created, not only a need to cut costs, but also, an incentive to provide organ transplants for high-paying foreign customers as a way of subsidizing wider domestic availability. ${ }^{22}$

Advances in medical science in China went hand-in-hand with a series of anti-crime campaigns that produced a steadily growing supply of body organs for transplant surgery. "In absence of proper legal safeguards for prisoners' rights, this caused the evolving relationship between China's surgical capacity, patient demand and organ supply to develop in a particularly abusive direction." 23

\section{B. Anti-Crime Campaigns}

Beginning in 1983, the government of the People's Republic of China, began a "crackdown on crime" campaign. Since this time the prison population has doubled. ${ }^{24}$ In addition, far more people are now being condemned to death and judicially executed each year in China than at any time since the early 1950's. ${ }^{25}$ According to official reports ${ }^{26}$ the number of people actually

20. Id. at 5 .

21. Id.

22. Id. at 5,6 .

23. Id. at 6 .

24. Id. at 18.

25. Id. at 5. Statistics on the number of death sentences and executions carried out in China are regarded as "state secrets" by the government and are never made public. According to most outside estimates, however, approximately 10,000 people were executed in 1983, the year of the first "crackdown" campaign, and annual totals remained high for the rest of the decade. According to Amnesty International, which monitors use of the death penalty worldwide, the numbers of death sentences and executions reported publicly by the authorities this decade are as follows: in 1990 there were at least 980 death sentences and 750 completed executions; the numbers were 1,650 and 1,050 respectively in 1991; and 1,891 and 1,079 in 1992. During 1993, at least 2,564 persons were sentenced to death, of whom at least 1,419 actually were executed. Id. at 5, n.8 (citing Amnesty International, China: The Death Penalty: Unprecedented Rise in Death Sentences and Executions Since September 1993, ASA 17/09/93, London, July 
executed in Henan Province alone between January and July 1989 increased 47.28 percent over the same period the previous year, while the number of those sentenced to death with a two-year suspension increased by 107.8 percent. ${ }^{27}$ As a result of legislative changes promulgated by the government since 1982, there are two and a half times as many criminal offenses punishable by the death penalty and almost three times as many articles of law stipulating capital punishment as there were prior to the introduction of the criminal law in $1979 .^{28}$

The President of the Supreme People's Court, Ren Jianxin has vowed to sentence to death anyone guilty of crimes that have harmed the country's image or jeopardized economic reforms. ${ }^{29}$ "Major corruption and bribery cases that have seriously infringed in the interest of the country and destroyed the reputation of the Communist party and the Government" are among those crimes punishable by death. ${ }^{30}$ Other crimes mentioned by Ren Jianxin are murder, rape, smuggling, fraud, production of false goods and tax fraud. Amnesty International reports that at least 1,890 death sentences were handed down in 1992. This is the highest figure since 1983 when an estimated 10,000 people were executed at the start of the "crack-down on crime" campaign. ${ }^{31}$

\section{VIOLATIONS OF CHINESE LAW}

\section{A. Temporary Rules Concerning the Utilization of Corpses or Organs from} the Corpses of Executed Criminals ${ }^{32}$

A directive issued jointly on October 9, 1984, by the Supreme People's Court, Supreme People's Procuracy, Ministry of Public Security, Ministry of Justice, Ministry of Health and Ministry of Civil Affairs, provides three ways in which organs may be removed from prisoners. ${ }^{33}$ First, if a prisoner's

1994, and China: Death Penalty in 1992, ASA 17/09/93, London, July 1993).

26. HUMAN RIGHTS WATCH/ASIA, supra note 1, at 18 (citing "Criminal Trial Work Report of the Henan Provincial High People's Court" (Henan Sheng Gaoji Renmin Fayuan Guanyu Xingshi Shenpan Gongzuo de Baogao), Aug. 25, 1989, in Renmin Fayuan Nianjian 1989 (1989 People's Court Yearbook), People's Court Press (Beijing: 1992), at 462).

27. Id.

28. Id. at 19.

29. Chris Yeung, Top Judge in Execution Vow, SOUTH CHINA MORNING POST, July 30, 1993, at 10.

30. Id.

31. Id. See also AMNESTY INTERNATIONAL REPORTS 1993.

32. Temporary Rules Concerning the Utilization of Corpses of Executed Criminals, October 9, 1984, reprinted in Human Rights Watch/ Asia, supra note 1, app. at 36.

33. Id. 
body is unclaimed by their family, the government may then take the organs. Second, the prisoner has volunteered his organs to be removed after his death. Third, the prisoner's family may consent to the donation of the organs.

\section{Unclaimed Corpse}

Following the execution of a prisoner, if the body is not claimed by his family, the government may then use the prisoner's organs for transplantation. However, often a family is not informed of the date of execution and has little or no contact with the condemned prisoner. "[Prisoners] are denied access not only to their families but to a defense lawyer, from the moment they are first detained and until a matter of days before trial. Since pre-trial detention often lasts from several months to more than a year, . . ${ }^{134}$ By the time a family learns of the execution, it may be too late for them to claim the remains, thus making it easier for the Chinese government to justify the use of organs by claiming that the body was not taken by the family. In addition, once the organs have been removed, the bodies are then cremated, so that a family claiming the body would not be able to determine whether the cremation occurred with the organs intact or not. ${ }^{35}$

\section{Voluntary Consent}

Second, where the executed criminal has volunteered to have his corpse provided to a medical treatment or health unit for use, the organs may then be removed. ${ }^{36}$ Voluntary consent by the prisoners is often not sought. ${ }^{37}$ According to Chinese law, a corpse cannot be used for dissection or organ transplantation purposes unless the consent of the person whose body is to be used or the consent of their family is first obtained. ${ }^{38}$ Even in the minority of cases where the consent is sought as required by law, it is likely that it is not genuine free consent. Based on the abusive circumstances of detention in China, from the time a person is first accused of a capital offense until the moment of his or her execution, any notion of "free and voluntary consent" is absurd..$^{39}$ A captured capital offender is kept in leg irons until trial. If the prisoner is sentenced to death, he will remain in leg irons and often in handcuffs continuously until he is executed. Prisoners are held in small dark

34. HUMAN RIGHTS WATCH/ASIA, supra note 1, at 23.

35. Id. at 15 n. 42.

36. HUMAN RIGHTS WATCH/ASIA, supra note 16, app. at 37.

37. HUMAN RIGHTS WATCH/ASIA, supra note 1, at 11.

38. Id at 10 .

39. Id. at 12 . 
cells where they are tortured by "severe beatings, the use of electric batons and shackles, deprivation of sleep and food, and exposure to extremes of cold or heat. ${ }^{40}$ The following account of conditions on "death row" was written by a retired prison guard in the Tianjin Municipal Jail:

There is a special place inside the jail for holding condemned prisoners-a long chamber comprising several "solitary quarters" $(d u j u)$, one cell for each evil felon. The door to the chamber is lined with black rubber, very heavy, like an "entrance to hell" designed by some devil. The corridor is dark and deathly quiet. No sounds at all can be heard apart from the footsteps of guards and the clinking of ankle-fetters. Each criminal is kept all alone in a tiny, narrow cell. The four walls are lined with thick, springy sheets of leather, and it is as dark as a coffin. If they wish to talk to the guards, prisoners must stand and speak through a surveillance hole in the door. All of the prisoners are in handcuffs and leg irons, which will not be removed before the time of their execution. In order to eat, drink or go to the toilet, they have to be helped by "general duties" staff (zayi, prisoners serving light sentences). Once transferred there, condemned prisoners are denied access to the [communal] latrine and are barred from reading newspapers or listening to the prison's educational broadcasts. The only recreation left to them is to doze lethargically or just sit there in blank contemplation. In effect, criminals sent to the "solitary quarters" have lost even their souls, for what awaits them is death. ${ }^{41}$

According to a former judge familiar with pre-execution procedures in China, prisoners still in shackles would be taken into interrogation rooms the night before their execution and they would be bound by a rope around their arms, wrists, and waist to a chair. A judge would then enter and announce the final rejection of appeal, read the final death warrant aloud, and request that the prisoner sign the document. If the prisoner refused, the judge would forcibly press his finger to an ink pad and stamp a fingerprint onto the sentencing document. The prisoner remained tied to the chair for the rest of the night. ${ }^{42}$ At no time are the prisoners asked if they are willing to have their organs removed after execution. In the rare cases they are asked, what would prevent the judge from forcibly pressing the prisoner's finger to an ink pad and stamp a fingerprint onto the consent form? Under these conditions, there is no meaningful possibility of "free consent" being given.

40. AMNESTY INTERNATIONAL USA, 1994 REPORT.

41. HUMAN RIGHTS WATCH/ASIA, supra note 1, at 13.

42. Id. at 14 . 
Moreover, if a prisoner expressly states that he does not want his organs to be removed after he is executed, the likelihood of his declaration not to donate his organs reaching his family is highly doubtful. According to confidential regulations issued by the Supreme People's Court in $1984,{ }^{43}$

[T] he people's court responsible for handling a condemned criminal over for execution should promptly examine any last will or statements made by the condemned criminal. . . . Those parts which are slanderous in nature or which make reactionary statements are not to be handed over to the person's family. . . sections complaining about grievances or alleged injustices are not to be passed on to the person's family. ${ }^{44}$

Since officials are directed to edit prisoners' wills and last statements for slanderous statements and grievances there is nothing to prevent them from omitting any expression by the prisoner of his intention to keep his organs. Officials have carte blanche with regard to manipulating any documents written by the prisoners. Unauthorized dissections and organ removal can be carried out by the authorities with impunity. ${ }^{45}$

\section{Family Consent}

Thirdly, the organs of executed criminals may be provided for use if the family consents to the use of the corpse. Often families are either not informed about the organ donation or they are offered cash payments in advance as an incentive to consent. ${ }^{46}$ It appears that families are given the choice to consent or to refuse but refusal to grant permission may result in the families being presented with large bills for the prisoner's food, other expenses, and even the cost of the bullet used for execution. ${ }^{47}$

\section{VIOLATIONS OF INTERNATIONAL LAW}

The United Nations Charter [Charter], to which China is a signatory, begins with the following language:

With a view to the creation of conditions of stability and well-

43. Id. at 12, n.33 (citing Circular Concerning the Correct Handling of Last Wills and Various Objects Left Behind by Criminals Condemned to Death, January 11, 1984).

44. Id.

45. Id. at 15 .

46. Id. at 14 .

47. Id. 
being which are necessary for peaceful and friendly relations among nations based on respect for the principle of equal rights and selfdetermination of peoples, the United Nations shall promote:

(a) higher standards of living, full employment, and conditions of economic and social progress and development;

(b) solutions of international economic, social, health, and related problems; and international cultural and educational cooperation; and

(c) universal respect for, and observance of human rights and fundamental freedoms for all without distinction as to race, sex, language, or religion. ${ }^{48}$

\section{A. Charter of the United Nations}

China has voluntarily accepted obligations under the Charter which requires it to ensure its citizens basic human rights. Upon admittance to the United Nations, China assumed an obligation under the Charter of the United Nations to take joint and separate action to "promote . . universal respect for, and observance of, human rights and fundamental freedoms for all . .." ${ }^{49}$ As a country, it is bound by established human rights standards, which are part of international law and have been accepted by the international community as interpreting the human rights provisions of the Charter.

The act of taking organs from prisoners without their consent is not consistent with the purposes and principles of the Charter. The Charter's purpose, inter alia, is to promote and encourage respect for human rights and fundamental freedoms for all. ${ }^{\text {so }}$ As one of the eleven members of the United Nations Security Council, China is to discharge its duties in accordance with the purposes and principles of the Charter. ${ }^{31}$ China is obligated to uphold fundamental human rights as a member of the United Nations, as well as a member of the Security Council. China's current behavior with respect to upholding the rights of its citizens raises serious doubt as to its abilit' to uphold its obligations as a member of both the United Nations and the United Nations Security Council.

48. U.N. CharTER art. 55. See GoOdrich \& HAMBro, Charter of the United Nations Commentary and Documents 319 (1949). China was an original signatory to the United Nations Charter on June 26, 1945 at the United Nations Conference in San Francisco, California. China then ratified the United Nations Charter on August 28, 1945, and the ratification was deposited on September 28, 1945. Id. at 545, 570.

49. Id. U.N. CHARTER arts. 55, 56.

50. Id. U.N. CHARTER art. $1, \S 3$.

51. Id. U.N. CHARTER art. $24, \S 2$. 


\section{B. International Covenant on Civil and Political Rights}

Article 7 of the International Covenant on Civil and Political Rights $(\text { ICCPR })^{52}$ states that "[no] one shall be subjected to torture or to cruel, inhuman or degrading treatment or punishment. In particular, no one shall be subjected without his free consent to medical or scientific experimentation." ${ }^{53}$

Although China is not a signatory to the ICCPR, the rights of criminal defendants under the ICCPR are fully embodied in China's criminal and procedural law. ${ }^{54}$ The provisions in the ICCPR reflect norms of customary international law and are therefore binding on states on that basis. ${ }^{55}$ Customary international law results from a general and consistent practice of states which is followed by them from a sense of legal obligation. ${ }^{56}$ In the highly codified humanitarian law context, the primary and most obvious significance of a norm's customary character is that it binds states not party to the instrument on which that norm is restated. ${ }^{57}$ Since Article 7 of the ICCPR is considered to be a customary norm of international law, then China is bound by it. Hence, China's taking of prisoners' organs without their consent, an action similar to subjecting one to non-volitional medical experimentation, violates Article 7. This article plainly states that consent must first be obtained before medical experimentation can take place.

The provisions of the ICCPR are declaratory of the law laid down in the Charter and therefore bind the members of the United Nations on that basis. ${ }^{58}$ A further argument that the ICCPR binds non-state parties is based on the foundation that certain of its provisions reflect "the general principles of law recognized by civilized nations." ${ }^{59}$ In other words, because Article 7 is recognized by most civilized nations and China considers herself a civilized nation, China is obligated to recognize it.

52. HUMAN RIGHTS: A COMPILATION OF INTERNATIONAL INSTRUMENTS, at 8, U.N. Doc. ST/HR/Rev.2, U.N. Sales No. E83. XIV.1 (1983). The ICCPR was adopted and opened for signature, ratification, and accession by General Assembly Resolution 2200A (XXI) of Dec. 16, 1966. ICCPR was entered into force on March 23, 1976. Id.

53. Id. at 9.

54. Report by the special Rapporteur, Mr. S. Amos Wako, pursuant to Commission on Human Rights resolution 1990/51, U.N. Commission on Human Rights, 47th Sess., Agenda Item 12, at 22, U.N. Doc. E/CN.4/1991/36 (1991).

55. Dominic McGoldrick, The Human Rights Committee: ItS Rule in the DEVELOPMENT OF THE INTERNATIONAL COVENANT ON CIVIL AND POLITICAL RighTS 21 (1991).

56. THEODOR MERON, HUMAN RIGHTS AND HuMANITARIAN NORMS AS CUSTOMARY LAW 3 (1989).

57. Id.

58. McGoldrick, supra note 55, at 21 .

59. Id. 


\section{Standard Minimum Rules for the Treatment of Prisoners}

China is in violation of a number of provisions set out in the Standard Minimum Rules for the Treatment of Prisoners (Standard Minimum Rules) ${ }^{60}$ Based on the account relayed by a retired prison guard, ${ }^{61}$ prisoners are kept in leg irons until trial and if sentenced to death, remain in leg irons until execution. ${ }^{62}$ According to the Standard Minimum Rules, "leg irons shall never be applied as punishment, or used as restraints." ${ }^{63}$ Furthermore, "the patterns and manner of use of instruments of restraints shall be decided by the central prison administration. Such instruments must not be applied for any longer time than is strictly necessary." Occasionally, prisoners may have to be restrained for long periods of time, an act contrary to the Standard Minimum Rules. Therefore, China's standard practice of constraining convicted criminals in leg irons until execution violates this provision. ${ }^{64}$

Section 36 (3) states "... that every prisoner shall be allowed to make a request or complaint, without censorship . ..,"65 but a directive issued by the Chinese government expressly directs officials to censor a condemned criminal's last will or statement. ${ }^{66}$ The directive is in direct violation of the Standard Minimum Rules. Prisoners are also regularly allowed under necessary supervision to visit or correspond with their family and reputable friends. ${ }^{67}$ However, families are often not even informed of their relatives incarceration so the opportunity to communicate and visit is controlled by the government, and if it so chooses, there is no visitation at all. ${ }^{68}$

Last, the conditions on "death row" as described by a retired prison guard directly contradicts the provision in section $39 .{ }^{69}$ The guard stated that once a prisoner is transferred to death row, he is barred from reading newspapers or listening to the prison's educational broadcasts. ${ }^{70}$ Section 39 of the Standard Minimum Rules is as follows: "Prisoners shall be kept informed regularly

60. Standard Minimum Rules for the Treatment of Prisoners thereinafter Standard Minimum Rules], reprinted in UNITED NATIONS, HUMAN RIGHTS A COMPILATION OF INTERNATIONAL INSTRUMENTS 75 (1983). The Rules should serve to stimulate a constant endeavor to overcome practical difficulties in the way of their application, in the knowledge that they represent, as a whole, the minimum conditions which are accepted as suitable by the United Nations. Id.

61. HUMAN RIGHTSWATCH/ASIA, supra note 1 , at 13.

62. Id.

63. Standard Minimum Rules, supra note 60, at 77.

64. HUMAN RIGHTS WATCH/ASIA, supra note 1, at 13.

65. Standard Minimum Rules, supra note 60 , at 78 .

66. HUMAN Rights WATCH/ASIA, supra note 1, at 11.

67. Standard Minimum Rules, supra note 60 , at 78.

68. HUMAN RIGHTS WATCH/ASIA, supra note 1 , at 23.

69. Standard Minimum Rules, supra note 60 , at 78.

70. HUMAN RIGHTS WATCH/ASIA, supra note 1, at 13. 
of the more important items of news by the reading of newspapers, periodicals, or special institutional publications, by hearing wireless transmissions, by lecture or similar means as authorized or controlled by the administration." ${ }^{71}$

\section{Code of Conduct for Law Enforcement Officials}

Article 1 of the Code of Conduct of Law Enforcement Officials ${ }^{72}$ (Code of Conduct) provides that "law enforcement officials shall at all times fulfill the duty imposed on them by law, by serving the community and by protecting all persons against illegal acts, consistent with the high degree of responsibility required by their profession. ${ }^{173}$ It is a law enforcement official's duty to protect all persons against illegal acts. Since non-volitional removal of prisoners' organs is illegal under Chinese law, ${ }^{74}$ the law enforcement officials are in violation of the Code of Conduct because they are not protecting the prisoners against illegal acts. Also, in performance of their duty, "law enforcement officials shall respect and protect human dignity and maintain and uphold the human rights of all persons. ${ }^{\text {"75 }}$ If a law enforcement official has reason to believe that a violation of the Code of Conduct has occurred, he shall report the matter to his superior and where necessary, to other appropriate authorities or organs vested with reviewing or remedial power. ${ }^{76}$ This provision clearly requires all law enforcement officials to report the illegal act of organ procurement from condemned prisoners to the proper authorities. By failing to report the illegal acts, they violate the Code of Conduct. This failure, especially since it occurs under color of law, puts China in clear violation of international law, and the international community must force China to cease its current practices.

\section{E. Principles of Medical Ethics}

The involvement of Chinese doctors and other medical personnel in the process of removing executed prisoners' organs is necessarily extensive. Blood

71. Standard Minimum Rules, supra note 60, at 78.

72. Code of Conduct of Law Enforcement Officials, reprinted in UNITED NATIONS, HUMAN RIGHTS: A COMPILATION OF INTERNATIONAL INSTRUMENTS 84, U.N. Doc. ST/HR/1/Rev. 2, U.N. Sales No. E. 83 XIV.1 (1983) [hereinafter Code of Conduct].

73. Id. The term "law enforcement officials" includes all officers of the law, whether appointed or elected, who exercise police powers, especially the powers of arrest or detention. Id.

74. HUMAN RIGHTS WATCH/ASLA, supra note 1 , at 39.

75. Code of Conduct, supra note 72 , at 84.

76. Id. at 86. 
tests are performed prior to execution to determine the prisoner's health and suitability as an organ donor. Medical personnel are also present at the execution, awaiting the moment of death so that they can immediately remove the organs and rush them back to the hospital to perform the operation. ${ }^{n}$

The involvement of medical professionals in the judicial execution and transplantation process represents a grave violation of internationally accepted standards of medical behavior. ${ }^{78}$ According to the United Nations' "Principles of Medical Ethics Relevant to the Role of Health Personnel, Particularly Physicians, in the Protection of Prisoners and Detainees Against Torture and Other Cruel and Inhuman or Degrading Treatment or Punishment," health personnel have a duty to provide prisoners with protection of their physical and mental health and treatment of disease of the same quality and standard as afforded to those who are not imprisoned or detained. ${ }^{79}$ Healthcare providers do not take organs from nonimprisoned Chinese citizens without consent; likewise, under the Principles of Medical Ethics, they should not remove prisoners' organs without consent.

The third tenet of the Principles of Medical Ethics mandates that: "[i]t is a contravention of medical ethics for health personnel, particularly physicians, to be involved in any professional relationship with prisoners or detainees the purpose of which is not solely to evaluate, protect or improve their physical and mental health. ${ }^{\text {"180 }}$ Organ removal does not fall into the category of evaluation, protection, or improvement of physical health and, therefore, health personnel who harvest prisoners' organs violate the Principles of Medical Ethics.

The last principle states that "it is a contravention of medical ethics for physicians to certify the fitness of prisoners for any form of treatment or punishment that may adversarily affect their physical or mental health or to participate in any way in the infliction of any such treatment or punishment which is not in accordance with the relevant international instruments. ${ }^{181}$ The role played by medical personnel in the execution and organ transplantation process in no way furthers the health of the prisoners involved. ${ }^{82}$ "Instead, it converts state-sponsored killing into a grotesque, quasi-medical operation. ${ }^{183}$ The physician's primary duty to safeguard life and health as set out in the principles of Medical Ethics is fundamentally corrupted by the practice of using executed prisoners as a source of organs.

77. HUMAN RIGHTS WATCH/Asta, supra note 1, at 31 . In addition, hospitais are notified ahead of time when the execution is to be held so they may arrange a donor patient match and prepare to make the transplant. Id.

78. Id.

79. Principles of Medical Ethics, reprinted in UNITED NATIONS, HUMAN RIGHTS: A COMPILATION OF INTERNATIONAL INSTRUMENTS 87, U.N. Doc. ST/HR/1/Rev. 2, U.N. Sales No. E. 83 XIV.1 (1983).

80. Id.

81. Id. at 87. See also id. Principle 4(b).

82. HUMAN RightS WATCH/ASIA, supra note 1 , at 32.

83. Id. 


\section{Proposed SOLUTIONS}

\section{A. Legally Effective Methods of Organ Procurement}

In place of the current reliance on executed prisoners as a source for organ procurement, the Chinese government should take vigorous steps and commit adequate resources toward establishing a comprehensive national program to encourage voluntary organ donation by the general public.

\section{Cadaveric Organ Donor Act}

The Cadaveric Organ Donor Act (CODA) is a proposed bill which is designed to alleviate the organ shortage in the United States. "CODA proposes a new, comprehensive, national approach to the donation of human organs for transplantation purposes with its National Organ Donor Registry and broad acceptance of the concept of mandated choice. ${ }^{184}$

If CODA, or a similar act is established in China, it could significantly increase the supply of available organs for transplantation. "Under CODA, every individual under the age of sixteen is provided an opportunity to file a National Organ Donor Registration Form (Donor Form) on which he can elect to be a donor of all organs, a donor of only some organs, or not to be a donor at all." 85 The Donor Form will accompany the individual's application for any form of identification (driver's license, passport, etc.). All elections are then filed on a National Organ Donor Registry. ${ }^{86}$ The National Registry would provide a single uniform database recording the decisions that citizens have made regarding their donative status. The database is made accessible to all health care institutions.

The status of an individual as a donor, restricted donor or non-donor can be changed at any time by the donor prior to death. The status of an individual over the age of sixteen may not be changed by anyone after the individual dies, including members of his or her family. ${ }^{87}$ Parents of a minor under the age of sixteen may elect to donate or refuse to donate their child's organs regardless of how the minor is listed in the National Registry. ${ }^{88}$ Upon the death of an individual whose organ donation decision was not officially recorded in the National Registry, medical authorities may presume that the individual or an appropriate decision maker has consented to the donation

84. Proposed Federal Statute, Cadaveric Organ Donor Act-Report, 18 J. CoRP. L. 543 , 544 (1993).

85. Id.

86. Id.

87. Id. at 545 .

88. Id. 
of all needed organs. ${ }^{89}$ If however, the decedent's family objects to the removal, then the organs will remain intact.

By implementing a system of mandated choice, China would raise the level of consciousness among its citizens by forcing them to make a choice of whether or not to donate their organs. Informing and educating the citizens of a country as large as China about voluntary organ donation will substantially increase donations. Several states in the United States have begun to experiment with a form of mandated choice through their driver registration system. ${ }^{90}$ In Colorado, for example, drivers are asked to state directly on their license whether they wish to be a donor. The reverse side of the license acts as an organ donor card. With this system, approximately sixty percent of all Colorado drivers are registered as organ donors. ${ }^{\text {9l }}$ If China implements an act similar to CODA, the purpose of which is to close the gap between the number of potential donors and the number of actual organ donors and thereby increase the supply of needed organs for transplantation, she would have no need to violate the human rights of executed prisoners.

\section{The Brain Death Criterion}

"China's current legal standard for determining the time of death is the moment at which the heart stops beating. ${ }^{192}$ Most other countries recognize the "brain-stem death" criterion as being a more accurate and scientific standard of clinical death. ${ }^{93}$ Non-living organ donors must have had irreversible brain injury such that two neurospecialists with no professional conflict of interest in organ donation or treatment recipient benefit, can unambiguously state that there is no possibility of higher level brain function recovery. ${ }^{94}$ These prospective donors are typically located in hospitals, are on mechanical ventilation, and are of a neurological status such that if the respirator is disconnected, inability to breathe leads to cardiac arrest. ${ }^{95}$ Recognition of the brain death standard would clearly be beneficial to China's supply situation, since it would allow broader access to non-prisoner sources of organs, for example, respirator-sustained accident victims. Because time is of the essence in organ transplantation, many organs are not suitable for transplantation unless taken from the donor immediately after death. By observing the brain-death criterion, the availability of usable organs will increase because the organs

89. Id.

90. Id. at $545,546$.

91. Id.

92. HUMAN RIGHTS WATCH/ASIA, supra note 1, at 29.

93. Id.

94. Ronald D. Guttman, M.D., The Meaning of "The Economics and Ethics of Alternative Cadaveric Organ Procurement Policies," 8 YALE J. on Reg. 453, 454 (1991).

95. Id. 
will not deteriorate while the donor is respirator sustained, thus allowing for more time to notify the recipient and coordinate the transplantation. Brain-death criterion coupled with a system of mandated choice would greatly improve China's organ deficiency. However, without an outright ban on the procurement of organs from prisoners, the new standard could well result in further serious human rights violations. ${ }^{96}$

\section{Presumed Consent}

One common suggestion for increasing the supply of organs and tissues is to utilize presumed consent law. There are at least sixteen countries with some version of presumed consent: Austria, Belgium, Czech Republic, Denmark, Finland, France, Greece, Israel, Italy, Japan, Norway, Poland, Singapore, Spain, Sweden, and Switzerland. ${ }^{97}$ In Finland, Greece, Italy, Japan, Norway, and Spain, presumed consent is weak because doctors first ascertain if the next of kin have any objections before proceeding. The results obtained in these countries have been disappointing. The disappointment has not resulted from widespread exercise of the "opt out"198 choice. The problem instead seems to be that despite having the legal right to harvest the organs of a deceased person who has not "opted out" without obtaining the consent of his relatives, hospital personnel are unwilling to proceed without family consent, and are understandably reluctant to approach grieving survivors about the subject. ${ }^{99}$

"Strong presumed consent laws however, exist in Austria, Czechoslovakia, Denmark, France, Israel, Poland, Singapore, and Switzerland, where organ or tissue recovery proceeds unless there is knowledge that the next of kin objects or that the decedent had objections prior to death." 100 "Under presumed consent, physicians and organ procurement personnel are presumed to have the individual's and surviving family members' consent to remove needed organs at death unless these potential suppliers expressly make their preferences to the contrary known beforehand." 101 If a person dies with harvestable organs, and he has not given express indications of being unwilling to donate

96. HUMAN RIGHTS WATCH/ASIA, supra note 1, at 31 .

97. Daphne D. Sipes, Does It Matter Whether There Is Public Policy Or Presumed Consent In Organ Transplantation?, 12 WHITTIER L. Rev. 505, 515 (1991).

98. "Opt out" is the term used to describe what a person does when the person expressly states that they do not wish to have their organs removed after death.

99. Gregory S. Crespi, Overcoming the Legal Obstacles To The Creation Of A Futures Market In Bodily Organs, 55 OHо ST. L. J. 53 (1994).

100. Sipes, supra note 97, at 515.

101. Roger D. Blair \& David L. Kaserman, The Economics And Ethics Of Alternative Cadaveric Organ Procurement Policies, 8 YALE J. ON REg. 403, 434 (1991). 
those organs, then he is presumed to have consented to their harvestation. ${ }^{102}$ (This presumption overrides any objections to donation asserted by the surviving kin of the decedent)

There are currently two types of presumed consent removal statutes in the United States: "quasi," which requires a search for the next of kin to obtain consent, if the search is successful; and "pure," which requires no search and no consent of the family. ${ }^{103}$ Both types of presumed consent statutes are typically limited to the removal of comeas and pituitary glands in the United States. The basic difference between the "quasi-" and "pure-types" is the former's requirement of a reasonable search for the next of kin. The pure-type requires no search for next of kin and allows removal without the family's consent so long as there is no known objection. ${ }^{104}$

Although a presumed consent law would likely increase the number of organs available for transplant, it is not free from criticism. First, it is exploitative in the sense that many people are reluctant to expressly revoke consent, which is necessary if one does not want the organs harvested. ${ }^{105}$ This policy has an unsound foundation, as it suggests that presumed consent works because people hesitate to object to something that they do not want done. ${ }^{106}$ Second, presumed consent may also exploit ignorance or temporary confusion. Most organs are harvested from accident victims. Their families may not take the affirmative step of objecting to organ removal at that critical point when a loved one dies either because they are unaware of the imminent removal of the organs or because they do not think about it in their time of grief. $^{107}$

\section{Market Based System of Kidney Procurement}

Advocating a market solution to the existence of excess demand is commonplace among economists and non-economists alike when the commodity in question is a standard product normally traded in the market. ${ }^{108}$ When the scarce resource in question is a human organ however, this suggestion is much less readily received. ${ }^{109}$ An organ market does not propose "barkers

102. Crespi, supra note 99 , at 53.

103. Sipes, supra note 97 , at 524.

104. Id.

105. Blair \& Kaserman, supra note 101, at 434. See also Sipes, supra note 97. Singapore enacted a strong presumed consent law in 1987. The Singapore law penalizes a person who opts out by giving him a lower waiting-list priority if he should ever need an organ transplant.

106. See Blair \& Kaserman, supra note 101, at 434.

107. Id.

108. Id. at 420.

109. Id. 
hawking human organs on the street corners," or "an auction in which desperate recipients bid against each other for life sustaining organs." 110 Nor do advocates of the market system envision transplant patients, or their agents, dickering for a heart or liver with families of the recently deceased. ${ }^{111}$ Finally, they do not advocate a market for organs from living donors. ${ }^{12}$

Advocates of the market system suggest adopting the following scenario as an arrangement to equilibrate demand and supply of cadaveric organs. Potential organ suppliers could be offered some fixed payment in exchange for entering into a binding contract that authorizes removal of one or more of their organs at death. ${ }^{113}$ This is known as a forward market for organs, in that payment would occur well in advance of expected delivery. ${ }^{114}$ It is important to note that a fundamental prerequisite for the functioning of the market-based system is the legal clarification of property rights in this area. Physicians must be entering confident that they have the legal right, or even obligation, to remove needed organs from the cadaver of a person who has executed a supply contract. ${ }^{15}$ The contract should not be subject to renegotiation or unilateral cancellation by the family of the deceased, but at the same time, it need not be irreversible. ${ }^{116}$ People should be allowed to buy back their agreement at any point for an appropriate price.

In addition to the forward market, a spot market for kidneys and other organs could be instituted as well. ${ }^{117}$ Under a spot market, the organ procurement firm would approach the surviving family members of potential donors. The representative would appeal to altruism and the opportunity to salvage something good (saving someone else's life) out of an otherwise tragic experience (the loss of the relative who is to be the donor) in exchange for payment. ${ }^{18}$

The additional kidneys that would become available under a market system would provide obvious direct benefits to recipients. Patients receiving these kidneys would experience improved health and be relieved of the tiring process of dialysis. ${ }^{119}$ There are several indirect benefits of a market system. First,

\section{Id.}

111. Id.

112. Id. In fact, an institutional market for cadaveric organs would, in all likelihood, drive out a market for organs from living donors, because for the majority of the population the opportunity cost of organs obtained from cadavers is substantially less than the cost of organs obtained from living donors. Id.
113. Id. at 421 .
114. Id.
115. Id. at 431 .
116. Id.
117. Id.
118. Id. at 427.
119. Id. at 429 . 
an increase in the quantity of cadaveric kidneys supplied should lead to improvements in tissue matching between the transplanted organs and their recipients. ${ }^{120}$ In addition, the increase in supply would allow surgeons to be more selective about the overall condition of the organs transplanted. ${ }^{121}$ The enhanced supply of organs expected under a market system would make greater selectivity possible, thereby improving cadaveric organ transplant success rate. $^{122}$

Second, an increase in the number of cadaveric kidneys made available for transplantation would permit a reduced reliance upon living donors. ${ }^{123}$ This would alleviate cost to living donors in terms of lost time from work, pain of major surgery, and risks that result from loss of kidneys. ${ }^{124}$ Third, people who donate kidneys also constitute the principal source of hearts and livers for transplantation. ${ }^{125}$ An increased number of kidneys harvested under a market regime will therefore be accompanied by an increased number of hearts, livers, and other organs. ${ }^{126}$ Thus, patients in need of these other organs will also benefit from adopting a market system of kidney procurement.

Fourth, an increase in the quantity of organs supplied is likely to lead to reductions in the cost of performing transplant operations, especially hearts and livers. ${ }^{127}$ For example, the cost of a kidney transplant has fallen from about $\$ 100,000$ to about $\$ 25,000$ over the $1962-1988$ period. ${ }^{128}$ Heart, liver, lung, pancreas, and other organ transplantations are now at a relatively early stage of development. A substantial increase in the number of such transplants performed annually could have a dramatic effect on the costs of these types of surgeries. ${ }^{129}$ As these costs fall, the treatment would become available to an increasing number of individuals in need of such operations.

While there is general agreement that potential recipients are dying while utilizable organs are being wasted, the commentators disagree sharply on whether allowing the commercial sale of organs would be an effective and acceptable means of dealing with the problem. ${ }^{130}$ Proponents argue that society cannot

120. Id.

121. Id.

122. Id.

123. Id. at $\mathbf{4 3 0 .}$

124. Id. These costs are no longer warranted by differential success rates between cadaveric and living donors. The continued reliance on the living donor is more likely due to the prolonged waiting period. An increase in the quantity of organs supplied would largely alleviate these problems. Id.

125. Id.

126. Id.

127. Id.

128. Id.

129. Id.

130. Crespi, supra note 99 , at 55 . 
rely upon the altruistic feelings of people to provide society with organs. Instead, society must capture people by appealing to their economic self-interest to ensure that the unpleasant tasks that need to be done are carried out. ${ }^{131}$

\section{B. Pressure From Outside Sources as a A Method to Halting Organ Harvesting in China's Prisons}

\section{United Nations}

The United Nations Special Rapporteur on extrajudicial, summary or arbitrary executions should take a more aggressive role in the investigation of the alleged human rights violations occurring in China's prisons. The Special Rapporteur receives communications from non-governmental organizations, individuals and sometimes governments, containing information concerning alleged human rights violations. Once a year the Special Rapporteur makes reports to the United Nations Committee on Human Rights. ${ }^{132}$ It is the responsibility of the Special Rapporteur to send different types of communications to various governments defined by the nature of the human rights violations occurring in that country. In most cases, it is the Special Rapporteur's primary concern to establish whether the state has complied with its obligation under international law to prevent violations of the right to life, or where extrajudicial, summary or arbitrary executions have already occurred, to investigate the case circumstances of the death, identify the perpetrators and impose appropriate sanctions. ${ }^{133}$

Concerning the reports and allegations received by the Special Rapporteur, there are two principal difficulties he is continuously confronted with. First, he is only mandated to act upon information about human rights violations which come before him. ${ }^{134}$ Therefore, if he finds himself in a situation where there are serious grounds to believe that extrajudicial, summary or arbitrary executions are being committed in certain countries, even if they are covered by extensive reports in the media, and he has not received any allegations, he cannot act. Second, the Special Rapporteur has to decide on the credibility of the allegation being made, or whether it is politically or otherwise motivated. The more information that the allegation contains

131. Id. at 56. "It is not from the benevolence of the butcher, the brewer, or the baker, that we expect our dinner, bur from their regard to their own interest, we address ourselves, not to their humanity but to their self-love, and never talk to them of our own necessities but of their advantages." Id., quoting ADAM SMITH, AN INQUIRY INTO THE NATURE AND CAUSES Of The WeAlth Of Nations 14 (Modern Library 1937) (1776).

132. U.N. ESCOR, 49th Sess., Agenda Item 12, at 2, U.N. Doc. E/CN.4/1993/46 (1992).

133. Id.

134. Id. at 4. 
concerning the particulars of the purported victim (full name, age, place of residence or origin, profession, marital status etc.) and the precise circumstances of the incident (date, place, description of how the event occurred, etc.) the more likely it is that the allegation will be considered credible and forwarded to the state concerned. ${ }^{139}$ In principle though, the Special Rapporteur transmits all allegations he receives unless he has serious grounds to believe that the information provided is not credible. ${ }^{136}$

If the Special Rapporteur receives an allegation and determines its validity, he then sends urgent appeals and follow-up letters to the government of the country in which the alleged violations are taking place. It is hoped that the governments concerned will support him in the matter by providing him with updated information on cases under investigation. The Special Rapporteur often receives replies which are incomplete. In some instances, replies are general in character and do not refer to the particular cases transmitted; sometimes governments address special issues related with the mandate, without going into details with regard to the cases, and some governments inform the Special Rapporteur that the cases are being investigated. ${ }^{137}$ Examples of complete replies would include assurances from the government that the offenders have been identified and brought to justice, and that measures have been undertaken to effectively prevent reoccurrence.

However, such assurances are not always an indication that the violations have ceased. It is the Special Rapporteur's primary concern to establish whether the state complied with its obligation under international law to prevent violations of the rights to life, or where extrajudicial, summary or arbitrary executions have already occurred, to investigate the cause and circumstances of the death, identify the perpetrator and impose necessary sanctions. Thus, it may be necessary to visit The People's Republic of China in order to evaluate the allegations by human rights groups and the media, that China is executing prisoners for the purpose of harvesting organs. On-site visits are the only means by which the Special Rapporteur can familiarize himself with the facts and report to the United Nations Commission on Human Rights so that the United Nations can act to halt the harvestation of prisoners' organs in China.

\section{Foreign Governments}

With advances in medical technology and the desire to prolong life comes an increase in the responsibilities of the international communities to ensure that proper measures are enacted to guard against the violation of basic human rights. Foreign governments, especially in the Asia region, should take steps

135. Id at 5.

136. Id.

137. Id. 
to discourage or bar their citizens from obtaining organ transplants in China until such time as rigorous regulations and procedures are enacted by the Chinese government to ensure that prisoners' organs are not involved and that any organs for such use have been obtained with full prior consent of the donors or their families. ${ }^{138}$

In order to discourage its citizens from traveling to China for organ transplantation, each country should implement an organ procurement program of its own to increase the availability of organs for its citizens. In addition, citizens of other countries should be made aware of the risks involved in the transplantation operation. Many people are not educated about the risks involved in transplantation surgery. The risks involved in traveling to China to receive an organ taken from a prisoner are substantially greater thatn in many countries. Due to the widespread disease in prisons and the lack of any pre surgical testing of organs, the risks of obtaining an organ infected with hepatitis or AIDS is far greater than if the transplant were to be performed in a country that had a system regulating such operations.

Not only should other nations discourage or bar its citizens from obtaining transplants in China, other nations should apply direct pressure on the Chinese government by refraining from entering into or continuing any current trade agreements until the government puts an end to its current activities. Only after the Chinese government stops killing prisoners to obtain organs should any country resume trade negotiations or agreements with China.

\section{Medical Establishments}

Foreign funding agencies, medical establishments and individual health practitioners should adopt a strict policy of non-participation in all People's Republic Of China government sponsored organ transplantation related research programs or academic gatherings. ${ }^{139}$ Foreign medical and pharmaceutical companies, such as Switzerland's Sandoz, which currently supply goods or services to China's organ transplant establishment should cease all such commercial activities until the Chinese authorities have demonstrated that executed prisoners' organs are no longer being used for transplant purposes. ${ }^{140}$

\section{CONCLUSION}

Organ transplantation is a relatively new procedure in the medical world and, although the procedure is becoming quite routine and the success rate

138. HUMAN RIGHTS WATCH/ASIA, supra note 1 , at 33 .

139. Id.

140. Id. 
continues to rise, one major problem still remains: the demand for organs far exceeds the available supply. As a result, China has been taking organs to be used for transplantation purposes from executed prisoners. The Chinese Government may rationalize this practice by a philosophy that, "it happens only in rare instances and it's what the prisoner owes to society." However, the fact that it occurs even in the first instance clearly violates both Chinese and international law. Yet directives issued by the Chinese government create ways for law enforcement officials to circumvent existing laws requiring consent prior to organ removal.

China should ban all further use of prisoners' organs for transplant operations, and should comply with the United Nations Charter, the International Covenant on Civil and Political Rights, the Standard Minimum Rules of the Treatment of Prisoners, the Code of Conduct for Law Enforcement Officials, and the Principles of Medical Ethics Relevant to the Role of Health Personnel, Particularly Physicians, in the Protection of Prisoners and Detainees Against Torture and Other Cruel, Inhuman or Degrading Treatment or Punishment. By implementing one of the proposed solutions suggested in this Comment, China would be able to solve the current shortage of organs available for transplant, and simultaneously comply with both its own laws and those of the international community. A comprehensive system of voluntary organ donation may seem to be far off in China's future, but every step in that direction is a step towards preserving the human rights of prisoners in China.

Allison K. Owen

* J. D. Candidate, 1996, Indiana University School of Law-Indianapolis; B.A. University of Colorado, 1987. 
